\title{
Estimating the Impact of ASEAN China Free Trade Agreement on Indonesia's Trade Balance
}

\section{Muhammad Arif Junaidi ${ }^{1}$}

${ }^{1}$ Applied Economics, Faculty of The Professions, University of Adelaide, Australia

Email: mr.arifjunaidi@gmail.com

\section{ARTICLE INFORMATION}

Received date

[18-11-2019]

Revision

[02-12-2019]

Accepted date

[04-12-2019]

\begin{abstract}
Using trade flows data of ASEAN countries and China from 2002 to 2017, this study estimates the impact of ACFTA on ASEAN countries and China's trade balance in general, and also for Indonesia's trade balance in specific by elaborating the impact of ACFTA on the trade flows both exports and imports. Using the gravity model and estimating by OLS and PPML, this paper finds that the impact of tariffs elimination due to the implementation of ACFTA increased exports and imports for ASEAN countries and China in general, and for Indonesia in particular. However, the aggregate trade balances of ASEAN member countries and China is zero since the impact of ACFTA on imports offset the impact of ACFTA on exports. Tariff's elimination due to the implementation of ACFTA on Indonesia shows a negative and statistically insignificant effect on imports and exports. Thus, tariffs have not played significant role on increasing Indonesia's exports and imports. As a result, the impact of ACFTA on Indonesia's trade balance cannot be quantified clearly since the impact of tariffs on exports and imports are not significant.
\end{abstract}

Keywords: ACFTA, ASEAN, Indonesia, tariffs, trade balance 


\section{INTRODUCTION}

Free Trade Agreements (FTAs) have spread widely throughout the modern world. Most countries today are involved in FTAs, either in the form of bilateral agreements, multilateral agreements, or regional agreements. According to Asian Development Bank data, the number of FTAs has increased significantly in last two decades. The first FTA was signed in 1960, with the number of FTAs increasing to 71 in 2004, and then more than doubling to 169 in 2019 (Asian Development Bank, 2019). FTAs are expected to provide member states with more access to international trade by eliminating or decreasing trade barriers such as import tariffs and quotas. They are designed to enhance trade between two or more countries so that all involved parties will benefit. These benefits include both trade as well as other aspects, such as investments (Lakatos and Walmsley, 2012).

The ASEAN China Free Trade Agreement (ACFTA) had a long journey before it settled as the comprehensive agreement it is now. According to the ASEAN Commission, ACFTA was first signed in November 2002, and has been fully implemented since 2010, with the elimination of all tariffs on all dutiable goods. The general purpose of the agreement is to eliminate or reduce trade barriers that had been created both by tariff and non-tariff measures on goods and services between ASEAN countries and China (ASEAN Commission, 2019). Consequently, the agreement was expected to increase imports and exports among member countries.

The impacts of free trade agreements have been discussed in the literature for many years. There are a relatively large number of studies that investigate the impact of FTAs. Some papers explain that free trade agreements and free trade areas yield a positive impact for states by increasing trade volumes (Yang and Martinez-Zarzoso, 2014). However, some other studies have argued that they did not bring a significant impact on trade flows, and have even worked to decrease the growth of exports (Dianniar, 2007; Anggoro, 2018; Atrifia, 2018). The impacts of free trade agreements therefore remain debatable.

Since its implementation, the effect of the ASEAN-China Free Trade Agreement has been debated in Indonesia. Some researchers have argued that ACFTA has brought valuable improvements for Indonesian exports, for goods such as plastic, rubber, mineral products, and footwear (Widyasanti, 2017). Meanwhile, other researchers have claimed that ACFTA has decreased the competitiveness of industries and has driven Indonesia from an exportbased to import-based industry (Kurniawati, 2013). Combining these two positions suggests that, while ACFTA has functioned to increase both imports and exports, imports have 
increased more than exports. Consequently, this implies that ACFTA has led to an increase in Indonesia's trade balance deficit.

To date, most of the research into the impact of ACFTA has focused on how this agreement has affected exports, imports, and industry competitiveness, but no study has yet given specific attention to the balance of trade, which is an important indicator for a country because it can be used to measure the strength of its economy as well as its international competitiveness (Hunegnaw \& Kim, 2017). Moreover, according to The Statistics Indonesia, Indonesia achieved a trade surplus of US\$662 million (ten-years average) before ACFTA was implemented, but had a trade deficit of US $\$ 3.78$ billion (ten-years average) after implementation. These figures indicate that the Indonesian trade balance performed better before ACFTA than after its implementation and, as a result, that the effect of ACFTA on Indonesia's trade flows has been questionable.

The purpose of this research paper is to examine whether ACFTA has affected Indonesia's balance of trade substantially, by analysing the impact of the elimination of tariffs on Indonesia's exports and imports to other ASEAN countries and to China. This paper therefore provides a comprehensive study of the ASEAN-China Free Trade Agreement and its impact on Indonesian trade flows in general, and on Indonesia's balance of trade specifically. In addition, this research also provides an overview of previous literature that has examined the impact of free trade agreements on various economic indicators.

\section{LITERATURE REVIEW}

According to the definition by the Asian Development Bank, a free trade agreement is a commitment of two or more countries to remove or reduce tariffs among member countries while keeping the original tariffs for trade with non-members of the agreement. However, these agreements sometimes are not only limited to reducing trade tariffs but also cooperating in other sectors such as investments. Some countries may also seek to develop stronger commitments towards trade cooperation regionally or with multilaterally, leading to free trade areas that include multiple countries, broader agreement sectors, and more comprehensive cooperation.

As the number of FTAs around the world rapidly increased over the last decade, discussion of the impacts of these agreements has also become more frequent. The first FTA which was signed on February 18, 1960, was established by The Latin American Free Trade Association (Loureiro and Iri-usp, 2018). Figure 1, below, displays the rise in the number of 
FTAs from 1975 to 2019. By 2019, more than 160 FTAs had been signed, and this figure is likely to continue to grow steadily in the coming years. Such rapid growth in the number of FTAs indicates that countries have high expectations that these agreements will bring benefits to their trade flows and economic outcomes.

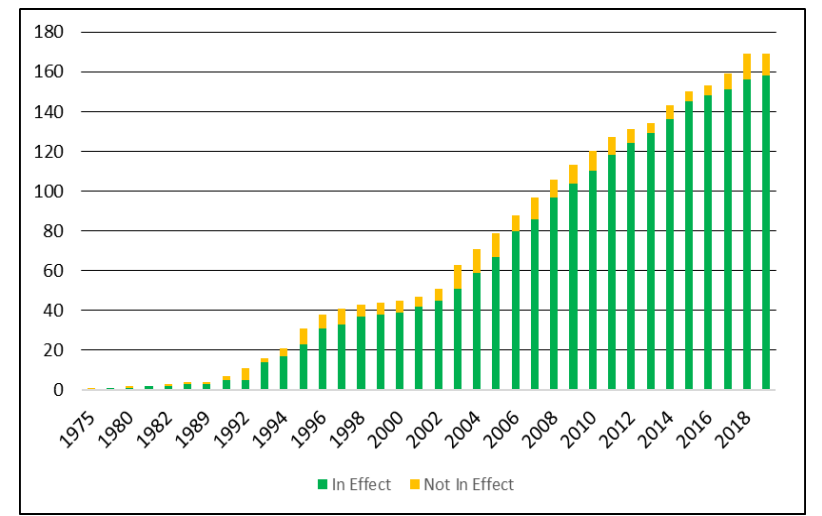

Figure 1. The Number of FTA Signed 1975-2019

Source: Asian Development Bank 2019

There are large number of studies investigating the impact of free trade agreements in particular countries. This research into the effects of implementing FTAs has found varying results; some positive, others negative, and still others finding a neutral or balanced effect in which neither positive nor negative effects occurred. Therefore, the empirical benefits of implementing FTAs remains questionable.

One study evaluating the impact of the China-Australia FTA (ChAFTA) on global coal production and trade using a computable partial equilibrium model found that the agreement brought about notable effects on trade creation, but relatively moderate effects on trade diversion. Moreover, after the agreement was brought into force, the export of Australian coal to China escalated over $35.5 \%$, and exports from China to Australia increased by over $19.9 \%$. In addition, the authors also demonstrated that, though ChAFTA will increase the annual welfare of Australia by US\$569.3 million, it will decrease the annual net welfare of China by US\$200 million (Xiang, Kuang and Li, 2017).

Most research into the impact of FTAs on welfare effects yields a positive result, with the majority of such studies using Computable General Equilibrium (CGE) as a tool of analysis (Rutherford, Rutstrom and Tarr, 1997; Siriwardana and Yang, 2008; Kitwiwattanachai). For instance, a research project into the impact of an FTA between Bangladesh and India found that the FTA generated welfare gains and an increase in real GDP for India, since India has a comparative advantage over various goods in the 
Bangladesh market. On the other hand, the welfare of Bangladesh was negatively affected by the FTA, resulting in a welfare loss and decline in real GDP (Kim and Ara, 2014).

Another study has elaborated on the impact of the ASEAN FTA (AFTA) on intraAFTA trade using the gravity equation (Okabe and Urata, 2014). The result of that study found that eliminating and lowering tariffs on a wide range of products led to a significant increase in trade creation. This means that the agreement among ASEAN countries has successfully promoted intra-AFTA trade. However, the tariff elasticities of imports tend to be higher than the tariff elasticities of exports (Okabe and Urata, 2014). In the other words, the larger the tariff reduction the higher possibility to import than to export, which results in trade deficits for countries.

In contrast to the large number of positive findings about the impacts of FTAs, other studies have argued that FTAs generate negative effects. Some researchers have shown that the increase in trade creation due to FTAs is not in fact significant, and that there are many other factors that could be causing a rise in trade (Hayakawa, 2014; Bhattacharyya and Mandal, 2016; Tongzon and Cheong, 2016; Atrifia, 2018). In addition, it is argued that trade agreements generate various results depending on the level of development of member countries. (Jang, 2011). As a result, FTAs encourage international trade based on vertical specialisation and promote deep integration among member countries, and the effects of FTA on trade flows depend on the pre-agreement vertical specialisation level and the level of integration of a country (Li, 2009).

In line with the mixed findings found in the exisiting research into FTAs, the impact of the ASEAN-China FTA, ACFTA, is similarly under debate. Some studies have found that ACFTA will provide benefits for some member countries, but others have found that ACFTA will lead to a negative effect for other countries. Some studies focus on trade creation and trade diversion effects, while others give attention to welfare effects.

Most of positive analysis of ACFTA argues that the agreement could raise the level of economic activities and enhance trade creation between member countries by increasing exports in many sectors such as agriculture and manufactured goods (Kurniawati, 2013; Indra Maipita, 2014; Sheng, Tang and Xu, 2014; Yang and Martinez-zarzoso, 2014; Yean, 2014; Indriyani, 2016; Ibrahim, Permata and Ari Wibowo, 2017; Widyasanti, 2017; Zhang et al., 2018). Moreover, many studies have also comprehensively described the positive relation between ACFTA and other economic performance indicators such as GDP growth, investment, and welfare (Lakatos and Walmsley, 2012; Li, Scollay and Maani, 2016; Li and Maani, 2018). 
For Indonesia, some researchers have argued that, although ACFTA may provide opportunities to increase trade flows, the increase in export growth after the implementation of the agreement has been less significant than the rate before Indonesia signed onto ACFTA (Ibrahim, Permata and Ari Wibowo, 2017). There is some empirical evidence supporting the idea that the implementation of ACFTA in Indonesia has had no significant impact on the trade flow of agricultural and manufactured goods (Dianniar, 2007; Anggoro, 2018). One explanation for this is that there are still significant trade barriers in China that could be serving to disrupt ASEAN exports to China. Consequently, ASEAN will experience strong competition from Chinese industries (Tongzon, 2005). Moreover, some economists have argued that the agreement between ASEAN and China exists because China requires more sources of natural resource input, and ASEAN can supply these (Chiratiphat, 2011).

The impact of ACFTA on other Indonesian economic performance indicators such output growth, welfare, and productivity level also yields negative results. Though China and other ASEAN countries may receive a positive impact on output growth, the elimination of tariffs has not led to an increase of output growth in Indonesia (Safuan, 2017). Furthermore, one researcher has attempted to compare the implementation of ACFTA in Indonesia and China with the agreement between Indonesia and Vietnam. The result of that study showed that the implementation of ACFTA provided less of a benefit to Indonesia than to China in terms of exports (Setiawan, 2012). Similarly, Vietnam is more likely to benefit from ACFTA than Indonesia, because Vietnam's geographically closer location next to China means that Vietnam is more likely to benefit (Vanzetti et al., 2011). To summarise, the implementation of ACFTA may yield an overall negative effect for Indonesia, with its distance from China one of the possible causes behind this.

As seen from the above discussion, the debate about the effect of FTAs in general remains contradictory, with previous studies into the implementation of FTA yielding various results due to their focuses on different countries, and use of different approaches and different methods of analysis. For the specific case of Indonesia, there have been a large number of studies on the impact of FTAs. That said, there has not yet been any study that focuses on the level of the trade balance in Indonesia. Therefore, this study aims to contribute to the literature by estimating the impact of ACFTA on Indonesia's trade balance.

In order to construct the hypothesis of the research, it started by looking the trade balance data of Indonesia and the overview of Indonesia's trade flow. Based on Figure 2, some ASEAN countries and China have a trade surplus after ACFTA's implementation, while other ASEAN countries face a trade deficit. Among these results, the most notable 
point is the pattern of the impact of ACFTA on ASEAN countries and China: countries that had a trade surplus before ACFTA enjoy a much higher trade surplus after ACFTA, as seen in the case of China, Malaysia, Singapore, and Thailand; while countries that had a trade deficit before ACFTA have shown even greater trade deficits after ACFTA, as in the case of Cambodia, Indonesia, the Philippines, and Vietnam. As a result, the implementation of ACFTA might lead to negative effect for Indonesia.

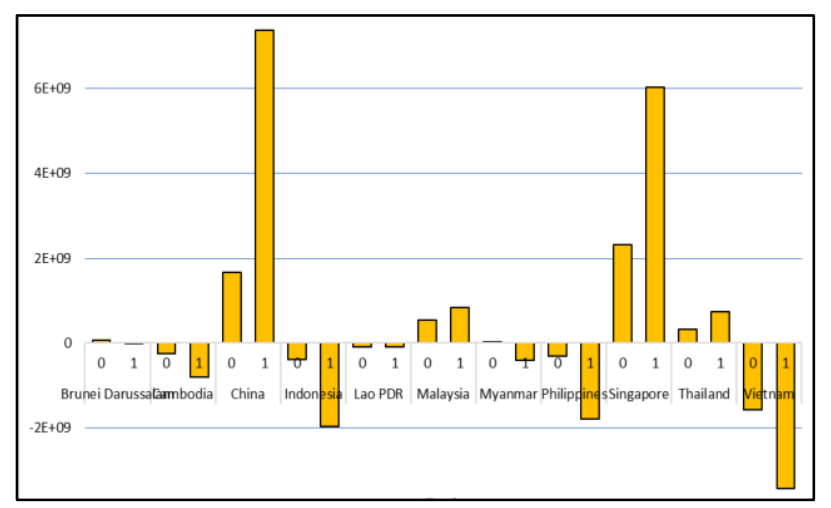

Figure 2. ASEAN and China's Trade Balance Before (0) and After (1) ACFTA Source: ASEAN Statistics Division 2019; author's calculation

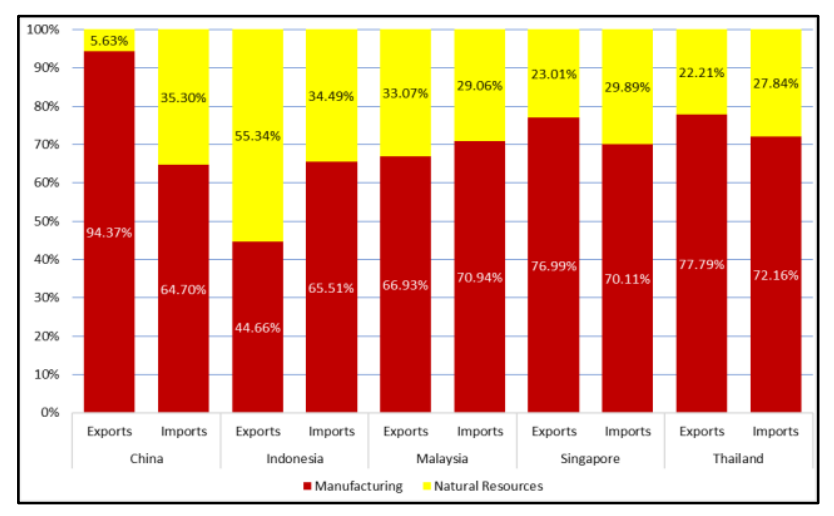

Figure 3. Proportion of Exports and Imports of Selected Countries 2015 Source: ASEAN Statistics Division 2019; author's calculation

Figure 3 shows that Indonesia's exports relied more on products derived from natural resources than on manufacturing products. The proportion of Indonesia's exports of natural resource products, at $55.34 \%$, is the highest among other ASEAN member countries and China. Meanwhile, the proportion of Indonesia's manufacturing exports are the smallest among the group. By contrast, Indonesia's imports are dominated by manufacturing products, rather than natural resource products. However, the proportion of Indonesia's manufacturing imports, at $65.51 \%$, is not much different to other ASEAN countries and China, which ranged between $64 \%$ to $72 \%$. 


\section{RESEARCH METHODS}

This study uses secondary data taken from various sources, including the Indonesian government and international institutions. Export and import data were collected from the ASEAN Statistics Division, which is an organization under direction of the ASEAN Committee. GDP data were acquired from the World Bank Development Indicator. Finally, geographical distance data were obtained from The Centre d'Etudes Prospectives et d'Informations Internationales (CEPII), which measures the distance between capitals.

Since the purpose of this paper is to analyse the impacts of ACFTA on Indonesia, which was fully implemented in 2010, data were collected for the period 2002-2017, encompassing eight years before and eight years after ACFTA's implementation. Export and import data reflect the bilateral trade flows between Indonesia, China, and all other ASEAN member countries. In addition, the GDP, import, and export data use US dollars as the currency, while distance data use kilometres (kms). GDP data collected from the World Bank Development Indicator was already in constant value using 2010 as the base year, while export and import data has been converted into constant value (2010 base year).

This research uses the gravity model, which was first proposed by Tinbergen. In order to estimate the impact of ACFTA on Indonesia's trade balance, the paper uses the structural gravity model proposed by Anderson and van Wincoop (2003), as follows:

[1] $\ln$ Import $_{i j t}=\alpha+\beta_{1} \ln G D P_{i t}+\beta_{2} \ln G D P_{j t}+\beta_{3} \ln$ Dist $_{i j}+\delta_{1}$ Tar $_{i j t}+$ Country $_{i}+$ Country $_{j}+\varepsilon_{i j t}$ [2] $\ln$ Export $_{i j t}=\alpha+\beta_{1} \ln G D P_{i t}+\beta_{2} \ln G D P_{j t}+\beta_{3} \ln$ Dist $_{i j}+\delta_{2}$ Tar $_{i j t}+$ Country $_{i}+$ Country $_{j}+\varepsilon_{i j t}$

Where Import $_{i j t}$ represents the import of country $\mathrm{i}$ from country $\mathrm{j}$ in time period $\mathrm{t}, G D P_{i t}$ represents the level of GDP for country $\mathrm{i}$ in time period t, GDP $P_{j t}$ represents the level of GDP for country $\mathrm{j}$ in time period $\mathrm{t}, \ln$ Dist $_{i j}$ represents the distance variable between country $\mathrm{i}$ and country $\mathrm{j}, \operatorname{Tar}_{i j t}$ is a dummy variable for import tariffs from country $\mathrm{i}$ to country $\mathrm{j}$ in time period $t$ where 1 is for the period in which tariffs are applied (at least one or both countries has not fully implemented ACFTA) and 0 for the period in which tariffs have been eliminated (ACFTA has fully implemented on both countries), Country $y_{i}$ and Country Cre $_{j}$ dummy variables for country $\mathrm{i}$ and country $\mathrm{j}$, while $\varepsilon_{j i t}$ refers to the error term.

The gravity model as stated in Equations [1] and [2] can be estimated by using cross sectional data and panel data. Although, panel data might more appropriate than crosssectional data due to more information included and increases the accuracy of the estimator but the factual information in microeconomic panel data is often exaggerated, 
because they are likely to show temporal and cross-sectional dependencies. Despite the fact that estimating cross-sectional data using Pooled Ordinary Least Square (OLS) suffers from a heteroskedatiscity assumption, OLS is still the best linear unbiased estimator, as stated by the Gauss-Markov theorem, since heteroskedasticity can be eliminated. In order to overcome this issue, Hoechle (2007) proposed a simple method using a robust standard error technique, which is used in this research.

Estimating a log-linear gravity model using ordinary least squares (OLS) may provide biased and inconsistent results. The basic issue is that the transformation of a gravity equation into log linear causes it to suffer from heteroskedasticity assumptions. This is because the log transformed error terms generally correlate with the covariates, since the probability of error terms being heteroskedastic is high in practice. The other problem of the log-linear transformation of the gravity model is the existence of zeros in trade data, which leads to imperfect solutions. As a result, the specification of the gravity equation proposed by Anderson and van Wincoop (2003), which includes country fixed effects, is considered to be biased and inappropriate if zero trade flows are present (Silva and Tenreyro, 2006).

Three years later, Silva and Tenreyro (2006) demonstrated a different estimation approach to deal with these problems, using the Pseudo Poisson Maximum Likelihood Estimator (PPML). PPML provides a consistent estimation of the basic non-linear gravity model, and can be used for both cross-sectional data and panel data. In addition, compared to other estimators such as OLS, FGLS, and GPLM, PPML is less influenced by heteroskedasticity (Martinez-Zarzoso, 2013). There are three properties of note regarding the application of PPML on the gravity model. First, PPML is consistent in the existence of fixed effects, which can be included as a dummy variable as in simple OLS. Second, the PPML estimator automatically includes zero trade values in the observation. Third, interpretation of the coefficient from the PPML estimator is as simple as under the OLS estimator. Hence, the PPML estimator is gaining popularity in the literature (Shepard, 2012), and will be included in this paper to support the Pooled OLS estimator.

\section{ANALYSIS AND DISCUSSION}

\subsection{The Impact of ACFTA on ASEAN Countries and China}

In order to investigate the impacts of ACFTA on ASEAN Countries and China's trade balances, this paper begins with analysing the effects of trade flow (exports and imports), then estimating the impacts of this on trade balance. The analysis is conducted using a Pooled OLS regression as shown in Table 1 and Table 3, with a PPML estimation 
as shown in Table 2 and Table 4. This paper uses a robust standard error technique to cope with the heteroskedasticity issue in the OLS regression.

Table 1. OLS Regression Result for ASEAN Countries and China

\begin{tabular}{|c|c|c|c|c|c|c|}
\hline VARIABLES & $\begin{array}{c}(1) \\
\text { Log Export }\end{array}$ & $\begin{array}{c}(2) \\
\text { Log Import }\end{array}$ & $\begin{array}{c}(3) \\
\text { Log Export }\end{array}$ & $\begin{array}{c}\text { (4) } \\
\text { Log Import }\end{array}$ & $\begin{array}{c}(5) \\
\text { Log Export }\end{array}$ & $\begin{array}{c}(6) \\
\text { Log Import }\end{array}$ \\
\hline Log GDPi & $\begin{array}{c}1.624 * * * \\
(0.030)\end{array}$ & $\begin{array}{c}1.393 * * * \\
(0.028)\end{array}$ & $\begin{array}{c}1.622 * * * \\
(0.030)\end{array}$ & $\begin{array}{c}1.392 * * * \\
(0.029)\end{array}$ & $\begin{array}{c}1.488 * * * \\
(0.432)\end{array}$ & $\begin{array}{c}1.058 * * * \\
(0.376)\end{array}$ \\
\hline Log GDPj & $\begin{array}{c}1.309 * * * \\
(0.026)\end{array}$ & $\begin{array}{c}1.620 * * * \\
(0.031)\end{array}$ & $\begin{array}{c}1.313 * * * \\
(0.026)\end{array}$ & $\begin{array}{c}1.626 * * * \\
(0.032)\end{array}$ & $\begin{array}{c}0.717 * * \\
(0.305)\end{array}$ & $\begin{array}{l}1.118 * * \\
(0.440)\end{array}$ \\
\hline Log Distance & $\begin{array}{c}-2.498 * * * \\
(0.077)\end{array}$ & $\begin{array}{c}-2.481 * * * \\
(0.084)\end{array}$ & $\begin{array}{c}-2.477 * * * \\
(0.080)\end{array}$ & $\begin{array}{c}-2.464 * * * \\
(0.087)\end{array}$ & $\begin{array}{c}-1.529 * * * \\
(0.088)\end{array}$ & $\begin{array}{c}-1.429 * * * \\
(0.093)\end{array}$ \\
\hline Tariffs & & & $\begin{array}{c}-0.761^{* * *} \\
(0.156)\end{array}$ & $\begin{array}{c}-0.745^{* * *} \\
(0.156)\end{array}$ & $\begin{array}{l}-0.204 \\
(0.155)\end{array}$ & $\begin{array}{l}-0.289 * \\
(0.159)\end{array}$ \\
\hline $\begin{array}{l}\text { Country FE } \\
\text { Year FE }\end{array}$ & & & Yes & Yes & $\begin{array}{l}\text { Yes } \\
\text { Yes }\end{array}$ & $\begin{array}{l}\text { Yes } \\
\text { Yes }\end{array}$ \\
\hline Constant & $\begin{array}{c}-37.202 * * * \\
(1.004)\end{array}$ & $\begin{array}{c}-39.483^{* * *} \\
(1.100)\end{array}$ & $\begin{array}{c}-36.248^{* * *} \\
(1.019)\end{array}$ & $\begin{array}{c}-38.565^{* * *} \\
(1.114)\end{array}$ & $\begin{array}{c}-27.456 * * \\
(12.861)\end{array}$ & $\begin{array}{c}-28.009 * * \\
(13.518)\end{array}$ \\
\hline Observations & 1,673 & 1,672 & 1,673 & 1,672 & 1,673 & 1,672 \\
\hline R-squared & 0.754 & 0.757 & 0.759 & 0.763 & 0.855 & 0.850 \\
\hline $\begin{array}{l}\text { Number of } \\
\text { Pairid }\end{array}$ & 110 & 110 & 110 & 110 & 110 & 110 \\
\hline
\end{tabular}

Table 1 estimates the impact of tariffs on ASEAN member countries and China's trade flow. These results show that the GDP, distance, and tariffs variables used in the gravity model explain more than $75 \%$ of the trade flows of the ASEAN countries and China's. Models (1) and (2) clearly show that all three explanatory variables are significantly related to export and import. In addition, the size of the economy of both trading partners has a positive impact on the increase of trade flow, which means that the increase of GDP leads to the increase of trade flow. Meanwhile, the distance between trading partners negatively impacts on exports and imports, which means that trade flows decline as distance between partners increases. These results provide broad empirical evidence for the basic gravity model.

The variable of interest of this paper, the tariff dummy variable, is negative for all models and is significant for all models except model (5), where it is not significant. Thus, it can be stated that the existence of tariffs reduced exports and imports in ASEAN 
countries and China. For instance, the coefficient of tariffs in model (5) for exports and model (6) for imports is -0.204 and -0.289 , respectively. This means that export tariff elasticities are lower than import tariff elasticities which is in line with the study from Okabe and Urata (2014). Therefore, given all other variables are constant, the existence of tariffs reduced ASEAN and Chinese exports by $18.5 \%$ and imports by $25.1 \%$. In other words, the elimination of tariffs through ACFTA increased the exports of ASEAN countries and China by $22.70 \%$, and the imports of ASEAN countries and China by $33.51 \%$ overall.

The impact of tariff elimination on trade balance can be examined by calculating the gap between the impact of tariff elimination on exports and the impact of tariff elimination on imports. However, considering the concept of trade flow, in which exports from country $i$ to country $j$ become the imports of country $j$ from country $i$, and vice versa, the impact of ACFTA on imports should be similar or close to the impact of ACFTA on exports. Looking at the results, the gap between the impact of ACFTA on exports and imports is quite large, so it can be inferred that the impact of ACFTA on general trade flow was between $22.70 \%$ and $33.51 \%$. Furthermore, the aggregate trade balances of ASEAN member countries and China counteract each other. In other words, the impact of ACFTA on the overall trade balance of ASEAN countries and China becomes zero since some countries receive trade surpluses and other countries receive trade deficits.

The large gap in the impact of ACFTA between exports and imports may have been caused by imperfect trade data due to the cut-off time for the reported data, differences in data reporting standards, or transportation issues. Each of these possibilities will now be discussed in turn. Firstly, in terms of missing reporting deadlines, if (for example) goods were exported in December 2014, but the importer received the goods in January 2015, the importer would have missed the reporting time frame for the data and, hence, both trading partners would report trade data differently. Secondly, differences in data can also have been caused by differences in data reporting standards - for example, Indonesia recorded the value of imports and exports by using FOB (Free on Board), while China declared its imports and exports data by using CIF (Cost Insurance and Freight). Thirdly, the transportation issues usually refer to the condition where an exporter country reports a higher figure than the importer country due to the unpredictable condition goods delivery. This may be caused by ships sinking, being hijacked, robbed, or smuggled. Any of these situations would mean the exports data for the sending country would differ from imports data for the receiving country. 
Table 2. PPML Result for ASEAN Countries and China

\begin{tabular}{|c|c|c|c|c|}
\hline VARIABLES & $\begin{array}{c}(1) \\
\text { Export } \\
\text { (Million US\$) } \\
\end{array}$ & $\begin{array}{c}(2) \\
\text { Import } \\
\text { (Million US\$) } \\
\end{array}$ & $\begin{array}{c}(3) \\
\text { Export } \\
\text { (Million US\$) } \\
\end{array}$ & $\begin{array}{c}(4) \\
\text { Import } \\
\text { (Million US\$) }\end{array}$ \\
\hline GDPi (in Billion US\$) & $\begin{array}{c}0.00027 * * * \\
(0.00004)\end{array}$ & $\begin{array}{c}0.00023 * * * \\
(0.00004)\end{array}$ & $\begin{array}{c}0.00024 * * * \\
(0.00004)\end{array}$ & $\begin{array}{c}0.00021 * * * \\
(0.00003)\end{array}$ \\
\hline GDPj (in Billion US\$) & $\begin{array}{c}0.00023^{* * * *} \\
(0.00004)\end{array}$ & $\begin{array}{c}0.00026^{* * *} \\
(0.00004)\end{array}$ & $\begin{array}{c}0.00021 * * * \\
(0.00004)\end{array}$ & $\begin{array}{c}0.00024 * * * \\
(0.00004)\end{array}$ \\
\hline Distance & $\begin{array}{l}-0.00006 \\
(0.00020)\end{array}$ & $\begin{array}{l}0.000029 \\
(0.00018)\end{array}$ & $\begin{array}{l}-0.00019 \\
(0.00019)\end{array}$ & $\begin{array}{c}0.00007 \\
(0.00018)\end{array}$ \\
\hline Tariffs & & & $\begin{array}{c}-0.44424 * * * \\
(0.15280)\end{array}$ & $\begin{array}{c}-0.39936^{* *} \\
(0.15850)\end{array}$ \\
\hline Constant & $\begin{array}{c}7.86253^{* * * *} \\
(0.51220)\end{array}$ & $\begin{array}{c}7.55818^{* * * *} \\
(0.47312)\end{array}$ & $\begin{array}{c}8.12842 * * * \\
(0.55929)\end{array}$ & $\begin{array}{c}7.79845 * * * \\
(0.51836)\end{array}$ \\
\hline Cluster in Pairid & 110 & 110 & 110 & 110 \\
\hline Parameter & 4 & 4 & 5 & 5 \\
\hline Observations & 1760 & 1760 & 1760 & 1760 \\
\hline Pseudo Log-likelihood & -7025107 & -6080277.8 & -6869242 & -5965732 \\
\hline R-squared & 0.243 & 0.319 & 0.234 & 0.301 \\
\hline Regressor excluded & 0 & 0 & 0 & 0 \\
\hline Observation excluded & 0 & 0 & 0 & 0 \\
\hline
\end{tabular}

The result of the PPML estimation reveals that the variables GDPi and GDPj were positive and statistically significant in all models. This means that the size of the economy is central to determining the trade flows of ASEAN countries and China. According to models (3) and (4), the GDPi coefficient reached 0.00024 and 0.00021, respectively. Accordingly, increasing GDP by USD \$10 billion will result in an increase in exports by USD \$2.4 million and imports by USD $\$ 2.1$ million. Meanwhile, the distance variable appears to not be statistically significant. This result suggests that the impact of distance on trade within ASEAN member countries and China is complex and more complicated than a straightforward negative effect.

Regarding the variable of interest of this paper, tariffs, the PPML estimator showed a different result to the OLS estimator in terms of the coefficient of the tariffs variable, due to the absence of year and country fixed effects. The PPML generated negative and statistically significant results for the tariffs variable, a result indicating that the existence of tariffs decreases the trade flows of ASEAN countries and China. This result confirms the result from OLS regression, even though the coefficient of tariffs variable is different. However, as explained in the OLS discussion above, the net impact of ACFTA on ASEAN and China's 
trade balances can be considered to be zero, since the impacts of ACFTA on exports counteracts the impacts of ACFTA on imports.

\subsection{The Impact of ACFTA on Indonesia}

Tariffs had similar effects on Indonesia's trade flow to their impacts on ASEAN countries and China. Table 3 shows that the GDP variable had a positive relation to the trade flow of either exports and imports, meaning that the bigger the size of the economy, the higher the trade flows. In the case of Indonesia, the result was statistically significant, with a value of 1.3 for the coefficient of exports and 1.61 for the coefficient of imports. These figures can be interpreted as indicating a 1\% increase of Indonesian GDP elevates the country's exports and the imports by $1.3 \%$ and $1.61 \%$, respectively.

Table 3. OLS Regression Result for Indonesia

\begin{tabular}{|c|c|c|c|c|c|c|}
\hline VARIABLES & $\begin{array}{c}(1) \\
\text { Log Export }\end{array}$ & $\begin{array}{c}(2) \\
\text { Log Import } \\
\end{array}$ & $\begin{array}{c}(3) \\
\text { Log Export }\end{array}$ & $\begin{array}{c}\text { (4) } \\
\text { Log Import }\end{array}$ & $\begin{array}{c}(5) \\
\text { Log Export }\end{array}$ & $\begin{array}{c}(6) \\
\text { Log Import } \\
\end{array}$ \\
\hline Log GDPi & $\begin{array}{c}0.949 * * * \\
(0.310)\end{array}$ & $\begin{array}{c}1.194 * * * \\
(0.387)\end{array}$ & $\begin{array}{c}0.944 \\
(0.696)\end{array}$ & $\begin{array}{c}0.183 \\
(0.749)\end{array}$ & $\begin{array}{c}1.300 * * * \\
(0.270)\end{array}$ & $\begin{array}{c}0.988 \\
(0.639)\end{array}$ \\
\hline Log GDPj & $\begin{array}{c}1.256 * * * \\
(0.048)\end{array}$ & $\begin{array}{c}1.617 * * * \\
(0.067)\end{array}$ & $\begin{array}{c}1.259 * * * \\
(0.049)\end{array}$ & $\begin{array}{c}1.597 * * * \\
(0.069)\end{array}$ & $\begin{array}{c}0.852 * * * \\
(0.167)\end{array}$ & $\begin{array}{c}1.613 * * * \\
(0.679)\end{array}$ \\
\hline Log Distance & $\begin{array}{c}-1.844 * * * \\
(0.117)\end{array}$ & $\begin{array}{c}-2.856 * * * \\
(0.174)\end{array}$ & $\begin{array}{c}-1.869 * * * \\
(0.129)\end{array}$ & $\begin{array}{c}-2.691 * * * \\
(0.190)\end{array}$ & $\begin{array}{c}-2.074 * * * \\
(0.502)\end{array}$ & $\begin{array}{c}-2.819 * * * \\
(0.193)\end{array}$ \\
\hline Tariffs & & & $\begin{array}{l}-0.573 * \\
(0.322)\end{array}$ & $\begin{array}{l}-0.690 * \\
(0.401)\end{array}$ & $\begin{array}{l}-0.032 \\
(0.091)\end{array}$ & $\begin{array}{l}-0.152 \\
(0.347)\end{array}$ \\
\hline Country FE & & & & & Yes & Yes \\
\hline Year FE & & & Yes & Yes & Yes & Yes \\
\hline Constant & $\begin{array}{c}-23.088^{* *} \\
(8.576)\end{array}$ & $\begin{array}{c}-31.738 * * \\
(11.056)\end{array}$ & $\begin{array}{l}--23.085 \\
(18.967)\end{array}$ & $\begin{array}{c}-4.867 \\
(20.559)\end{array}$ & $\begin{array}{c}-52.969 * * * \\
(7.161)\end{array}$ & $\begin{array}{l}-26.165 \\
(17.701)\end{array}$ \\
\hline Observations & 160 & 160 & 160 & 160 & 160 & 160 \\
\hline R-squared & 0.878 & 0.832 & 0.884 & 0.842 & 0.992 & 0.952 \\
\hline $\begin{array}{l}\text { Number of } \\
\text { Pairid }\end{array}$ & 110 & 110 & 110 & 110 & 110 & 110 \\
\hline
\end{tabular}

Robust standard errors in parentheses

$* * * \mathrm{p}<0.01, * * \mathrm{p}<0.05, * \mathrm{p}<0.1$

Source: Author's calculation using STATA

On the other hand, the distance variable had a negative sign and significance in all models used in this study. This means that Indonesia is more likely to trade with closer trading partners than with more distant trading partners. Furthermore, it is interesting to note that the gap between the coefficient of the distance variables in model (5) and model (6) was relatively large. This coefficient for the exports equation was -2.074 , while for the imports 
equation it was -2.819 ; indicating that the elasticities of distance for Indonesia's imports is larger than for its exports.

This distance coefficient result underlines the fact that Indonesia's imports and exports encompass different types of product. Most of Indonesia's imports are manufacturing products, while most its exports are natural resources or primary sector products. Trade in natural resources has less elasticity than manufactured products, because natural resources are important for the production processes of many manufacturing industries. As a result, the impact of the distance variable on Indonesian exports is less significant than the impact on its imports.

Although the tariffs variable in models (5) and (6) are insignificant, all showed the same sign, which was a negative relation to the ASEAN countries and China's trade flows for both exports and imports. The existence of tariffs will therefore decrease the amount of Indonesia's exports and imports, while the elimination of tariffs will increase its exports and imports. However, the results indicated that tariffs have not played a significant role in determining Indonesia's trade flow of either exports or imports. Hence, the increase of the country's exports and imports may be driven by other variables that are not observed in this model. As a result, based on the OLS result, the overall impact of ACFTA on Indonesia's trade balance could not be estimated.

A surprising finding was the difference between results in the significance of the tariffs variable in models (3) and (4) compared to models (5) and (6). In models (3) and (4), which did not involve country fixed effects, the variable showed statistical significance, while in models (5) and (6), which include country fixed effects, showed no statistical significance. It can be inferred that the country fixed effect is dominating the effect of tariffs, since the tariff elimination following ACFTA was implemented in two different phases, ASEAN-6 after 2010 and CLMV after 2015. Hence, country fixed effects would take over the effects of tariffs and generate an unclear estimation. As a result, the impact of ACFTA on Indonesia's trade balance cannot be identified clearly, because the impacts of tariffs on exports and imports cannot be estimated cleanly.

Table 4. PPML Result for Indonesia

\begin{tabular}{ccccc}
\hline VARIABLES & $\begin{array}{c}(1) \\
\text { Export } \\
\text { (in Million) }\end{array}$ & $\begin{array}{c}(2) \\
\text { Import } \\
\text { (in Million) }\end{array}$ & $\begin{array}{c}(3) \\
\text { Export } \\
\text { (in Million) }\end{array}$ & $\begin{array}{c}\text { (4) } \\
\text { Import } \\
\text { (in Million) }\end{array}$ \\
\hline GDPi (in Billion US\$) & 0.00061 & 0.00068 & -0.00005 & 0.00011 \\
GDPj (in Billion US\$) & $(0.00083)$ & $(0.00093)$ & $(0.00052)$ & $(0.00058)$ \\
& $0.00045^{* * *}$ & $0.00055^{* * *}$ & $0.00044 * * *$ & $0.00055^{* * *}$ \\
& $(0.00014)$ & $(0.00017)$ & $(0.00013)$ & $(0.00015)$
\end{tabular}




\begin{tabular}{|c|c|c|c|c|}
\hline Distance & $\begin{array}{l}-0.00062 \\
(0.00038)\end{array}$ & $\begin{array}{l}-0.00084 * \\
(0.00043)\end{array}$ & $\begin{array}{l}-0.00058^{*} \\
(0.00034)\end{array}$ & $\begin{array}{c}-0.00080 * * \\
(0.00039)\end{array}$ \\
\hline Tar & & & $\begin{array}{l}-0.31531 \\
(0.38850)\end{array}$ & $\begin{array}{l}-0.26024 \\
(0.50720)\end{array}$ \\
\hline Constant & $\begin{array}{c}8.78397 * * * \\
(0.64335)\end{array}$ & $\begin{array}{c}9.24095 * * * \\
(0.62089)\end{array}$ & $\begin{array}{c}9.39640 * * * \\
(0.93587)\end{array}$ & $\begin{array}{c}9.75361 * * * \\
(1.08887)\end{array}$ \\
\hline Cluster in Pairid & 10 & 10 & 10 & 10 \\
\hline Parameter & 4 & 4 & 5 & 5 \\
\hline Observations & 160 & 160 & 160 & 160 \\
\hline Pseudo Log-likelihood & -259523 & -354553 & -256811 & -352385 \\
\hline R-squared & 0.447 & 0.503 & 0.427 & 0.491 \\
\hline Regressor excluded & 0 & 0 & 0 & 0 \\
\hline Observation excluded & 0 & 0 & 0 & 0 \\
\hline
\end{tabular}

The PPML results for Indonesia in Table 9 show a similar result to the OLS results. The GDPi variable, which represents the GDP level of Indonesia, was statistically insignificant to leverage the trade flows of both exports and imports. This may be explained by other unobserved variables, such as the year fixed effect. Meanwhile, the GDPj variable, which represents the GDP level of Indonesia's trading partner, was positive and statistically significant in boosting the trade flows of Indonesia. Besides this, the distance variable was negative and statistically significant, indicating that Indonesia prefers to trade with closer rather than distant trading partners.

Although all of the tariff variables show statistical insignificance, both tariff coefficients from models [3] and [4] produced the same sign, which was negative. This implies that the implementation of tariffs will diminish the willingness of Indonesia to import and export, and conversely that the elimination of tariffs will encourage Indonesia to raise its exports and imports. This result supports the results of the OLS estimation, which concluded that tariff elimination did not have a significant effect on trade flows for either exports or imports. Hence, the impact of ACFTA on Indonesia's trade balance cannot be reliably calculated.

\section{CONCLUSION}

The objective of this paper was to analyze the impacts of the ASEAN-China Free Trade Agreement on Indonesia's trade balance by examining the impact of tariff elimination on Indonesia's exports and imports. Analysis began by investigating the impacts of ACFTA on ASEAN member countries and China in general, and then examining the impact of ACFTA on Indonesia specifically. In order to achieve the aims of this research, this paper 
used the gravity model suggested by Anderson and van Wincoop, and estimated by using the Pooled OLS and PPML estimators. This study used trade flows data, of both exports and imports, for ASEAN countries and China from 2002-2017.

The empirical results of this study indicate that a country's GDP has a positive and statistically significant effect on trade flows, both in terms of exports and imports, for ASEAN countries and China in general, as well as for Indonesia specifically. Counter to this GDP variable, the distance variable showed a negative sign, meaning that the more geographically distant two countries are, the lower the possibility to trade. However, the distance variable was statistically insignificant in the PPML results, which might mean that the impact of distance on trade within ASEAN countries and China is more complicated.

The impacts of tariff elimination due to the implementation of ACFTA increased exports and imports for ASEAN countries and China in general, and for Indonesia in particular. Since an export for one country is an import for another country, and vice versa, the impact of ACFTA on imports should be the same or close to the same as the impact of ACFTA on exports. Accordingly, the aggregate trade balances of ASEAN member countries and China counteract each other. In other words, the impact of ACFTA on the overall trade balance of ASEAN countries and China was zero, since some countries received trade surpluses, and some received trade deficits.

An interesting finding of this study is that the elasticities of distance for Indonesia's imports is larger than that for its exports. This finding reflects the fact that Indonesia has different types of products for import and export. Most of its imports are manufacturing products, while most of its exports are natural resources or primary products. Natural resources trade is less elastic than manufacturing products trade, because natural resources are important for the production processes in many manufacturing industries and have different transport characteristics. As a result, the impact of distance on Indonesian exports has a smaller effect than the impact of distance on Indonesian imports.

Overall, the tariff elimination due to the implementation of ACFTA showed a negative and statistically insignificant effect on Indonesia's imports and exports, which means that the elimination of tariffs may have increased the exports and the imports of Indonesia, but that this effect is not very clear. It can therefore be concluded that the elimination of tariffs has not played a significant role on Indonesia's trade flows, and that the increase of the country's exports and imports may be driven by other variables that are not included in the model of this study. Consequently, the impact of ACFTA on Indonesia's trade balance 
cannot be quantified clearly since the impact of tariffs on exports and imports was not significant.

\section{LIMITATIONS AND SUGGESTIONS}

This paper conducts a country-level analysis of overall trade flows (not on specific types of goods or sectors), and focuses on ASEAN countries as well as Indonesia. However, there are a number of limitations of this study. These limitations include Indonesia's involvement in many FTAs, such as the ASEAN Free Trade Area (AFTA), ASEAN-China Free Trade Agreement (ACFTA), Indonesia Japan Economic Partnership Agreement (IJEPA), and many others. This research focuses solely on the impacts of ACFTA on Indonesia's trade flows, because this agreement is one of the largest FTAs for Indonesia in terms of volumes of trade. Added to this, the implementation of ACFTA was divided into stages from the initial signing in 2002 until its completion in 2010. This staggering effect of tariff eliminations will be ignored in this paper, as the relative importance of tariff reductions in different sectors and industries cannot be ascertained with sufficient precision. Consequently, the implementation of the FTA is simplified into a single stage with the full completion of ACFTA by all ASEAN countries and China.

This study represents a research starting point for analysis of the impacts of free trade agreements on the balance of trade, and there therefore remains much scope for improvements in future research. Firstly, results could be clearer if the study's scope of analysis is not for overall trade flows, but for specialized products or sectors such as the manufacturing sector, agricultural sectors, etc. Secondly, this research assumed there is no staggering effect of tariff reduction, and so future studies may wish to proceed without this assumption. Thirdly, this paper used a limited set of explanatory variables, which can be improved by adding more explanatory variables in future studies. Finally, the geographic scope of further research could be expanded to include trade flows with non-ACFTA member countries as well.

\section{ACKNOWLEDGEMENT}

In the name of Allah, the Most Gracious and the Most Merciful. Alhamdulillah, all praises to Allah for giving me the health, the energy, and the knowledge to accomplish this paper. I would like to express my sincere gratitude to my supervisor, Dr. Florian Ploeckl, for his patience, motivation, enthusiasm, and immense knowledge. He always held the door 
open for discussion, provided me with materials, and guided me in the process of writing the research.

\section{REFERENCES}

Anderson, J. and van Wincoop, E. (2003) 'Gravity with gravitas: a solution to the border puzzle', NBER working paper series, 3(No.8079), pp. 1-37.

Anggoro, H. A. (2018) 'ASEAN-China Free Trade Area (ACFTA) Impacts on Indonesia's Manufactured Goods Trade Flow.

ASEAN Commission (2019), Retrieved from https://asean.org/asean-economiccommunity/asean-free-trade-area-afta-council/

Asian Development Bank (2019), Asia Regional Integration Center, Retrieved from https://aric.adb.org/fta-trends-by-status

Atrifia, A. (2018) 'The Impact of Indonesia-Japan Economic Partnership Agreement (IJEPA) on Indonesia's Trade Flow.

Bhattacharyya, R. and Mandal, A. (2016) 'India - ASEAN Free Trade Agreement: An ex post evaluation', Journal of Policy Modeling. The Society for Policy Modeling, 38(2), pp. 340-352.

Chiratiphat, S. (2011) 'ASEAN China Free Trade Area,: Background, Implication, and Future Development', The Chinese Economy, 43(3), pp. 68-76.

Dianniar, U. (2007) 'The Impacts of Free Trade Agreements on Trade Flows', RIETI Discussion Paper.

Hayakawa, K. (2014) 'Impact of diagonal cumulation rule on FTA utilization: Evidence from bilateral and multilateral FTAs between Japan and Thailand', Journal Of the Japanese And International Economies. Elsevier Inc., 32, pp. 1-16.

Hoechle, D. (2007) 'Robust standard errors for panel regressions with cross-sectional dependence', Stata Journal, 7(3), pp. 281-312.

Hunegnaw, F. B. and Kim, S. (2017) 'Foreign exchange rate and trade balance dynamics in East African countries', Journal of International Trade and Economic Development., 26(8), pp. 979-999.

Ibrahim, I., Permata, M. I. and Ari Wibowo, W. (2017) 'Dampak Pelaksanaan ACFTA Terhadap Perdagangan Internasional Indonesia', Buletin Ekonomi Moneter dan Perbankan, 13(1), pp. 23-74.

Indra Maipita (2014) The Impact Of Free Trade Between Asean And China on the Indonesian Households. 
Indriyani, I. (2016) 'The Effect of ASEAN-China Free Trade Area (ACFTA) on Indonesia Export', ETIKONOMI,15(2), pp.125-138.

Jang, Y. J. (2011) 'The Impact Of Bilateral Free Trade Agreements On Bilateral Foreign Direct Investment Among Developed Countries', World Economy, 34(9), pp. 16281651 .

Kim, C. and Ara, L. A. (2014) 'Economic Impact Of The Proposed Bangladesh - India FTA: Potentials And Realities', South Asian Journal of Global Business Research, 3(2), pp. 135-153.

Kitwiwattanachai, A., Nelson, D. and Reed, G. (2010) 'Quantitative Impacts of Alternative East Asia Free Trade Areas : A Computable General Equilibrium (CGE) assessment', Journal of Policy Modeling. The Society for Policy Modeling, 32(2), pp. 286-301.

Kurniawati, I. (2013) 'Dampak ACFTA Terhadap Perdagangan Sektor Industri dan Pertanian Indonesia (Studi Komparatif Indonesia-China dan Indonesia-Vietnam)', EkoRegional, 9(2), pp. 114-124.

Lakatos, C. and Walmsley, T. (2012) 'Investment Creation And Diversion Effects of the ASEAN-China Free Trade Agreement', Economic Modelling. Elsevier B.V., 29(3), pp. 766-779.

Li, Q. and Maani, S. (2018) 'Detecting positive effects of the ASEAN-China free trade agreement on foreign direct investment', International Economics and Economic Policy 15(1), pp. 69-87.

Li, Q., Scollay, R. and Maani, S. (2016) 'Journal of Asian Economics Effects on China and ASEAN of the ASEAN-China FTA: The FDI perspective', Journal of Asian Economics. Elsevier Inc., pp. 1-19.

Li, X. (2009) 'Free Trade Agreements and Vertical-Specialisation in East Asia', Asia Europe Journal, 7(1), pp. 145-160.

Loureiro-IRI-USP, F. and Schor-IRI-USP, A., 2018. Patterns of Argentine-Brazilian Bilateral Trade in the Post-War Era: the Effects of the Latin American Free Trade Agreement (LAFTA), 1945-1980

Martinez-Zarzoso, I. (2013) 'The Log Of Gravity Revisited', Applied Economics, 45(3), pp. $311-327$.

Okabe, M. and Urata, S. (2014) 'The Impact Of Afta On Intra-AFTA trade', Journal of Asian Economics. Elsevier Inc., 35, pp. 12-31. doi: 10.1016/j.asieco.2014.09.004.

Rutherford, T. F., Rutstrom, E. E. and Tarr, D. (1997) 'Economic Modelling Morocco's Free Trade Agreement with the EU : A quantitative assessment', Economic Modelling, 
14, pp. 237-269.

Safuan, S. (2017) 'ASEAN-China Free Trade Area: An Assessment Of Tariff Elimination Effect On Welfare', European Research Studies Journal, 20(4), pp. 27-37.

Setiawan, S. (2012) 'ASEAN-China FTA: The Impacts on The Exports of Indonesia and China', Buletin Ilmiah Litbang Perdagangan Vol. 6 No. 2 Bulan Desember 2012, (2), pp. 1-27.

Sheng, Y., Tang, H. C. and Xu, X. (2014) 'The impact of the ACFTA on ASEAN - PRC Trade: Estimates Based On An Extended Gravity Model For Component Trade', Applied Economics. Routledge, 46(19), pp.2251-2263.

Silva, S. and Tenreyro, S. (2006) 'The Log Of Gravity', The Review of Economics and Statistics, pp. 641-658

Siriwardana, M. and Yang, J. (2008) 'GTAP Model Analysis Of The Economic Effects of an Australia-China FTA: Welfare and sectoral aspects', Global Economic Review, 37(3), pp. 341-362.

Tongzon, J. and Cheong, I. (2016) 'The ASEAN-Korea Trade In Services (AKTIS) Agreement: Its Impact on Indonesia and Other ASEAN Countries', Bulletin of Indonesian Economic Studies, 52(1), pp. 101-117.

Tongzon, J. L. (2005) 'Tongzon 2005 - ASEAN- China Free Trade Area, A Bane or Boon for ASEAN Countries’. Blackwell Publishing.

Vanzetti, D. et al. (2011) 'A comparison of Indonesian and Vietnamese approaches to agriculture in the ASEAN-China FTA', in 55th AARES Annual Conference.

Widyasanti, A. A. (2017) 'Do Regional Trade Areas Improve Export Competitiveness? - a Case Of Indonesia', Buletin Ekonomi Moneter dan Perbankan, 13(1), pp. 5-22.

Xiang, H., Kuang, Y. and Li, C. (2017) 'Impact of the China-Australia FTA on global coal production and trade', Journal of Policy Modeling. The Society for Policy Modeling, 39(1), pp. 65-78.

Yang, S. and Martinez-zarzoso, I. (2014) 'China Economic Review A Panel Data Analysis Of Trade Creation And Trade Diversion Effects : The Case of ASEAN - China Free Trade Area', China Economic Review. Elsevier Inc., 29, pp. 138-151.

Yean, T. S. (2014) 'Re-examining the Impact of ACFTA on ASEAN's Exports of Manufactured goods to China', Asian Economic Papers, 13(1), pp. 84-103.

Zhang, L. et al. (2018) 'Who rides the tide of regionalization: Examining the effect of the China-ASEAN Free Trade Area on the exports of Chinese firms', International Business Review. Elsevier, 27(3), pp. 501-513. 